\title{
Transformation of Myelodysplastic Syndrome to Acute Lymphoblastic Leukemia in a Child
}

\author{
Vineeta Gupta • Baldev Bhatia
}

Received: 2 June 2009/ Accepted: 26 April 2010/Published online: 13 October 2010

(C) Indian Society of Haematology \& Transfusion Medicine 2010

\begin{abstract}
Childhood myelodysplastic syndrome (MDS) is an uncommon condition. Unlike adult MDS, pediatric patients have a more progressive course and rapidly transform to acute myeloid leukemia. Evolution to acute lymphoblastic leukemia is extremely rare. We report a 5 year old female child who presented with refractory anemia with excess blasts and transformed into acute lymphoblastic leukemia 4 months after initial diagnosis.
\end{abstract}

Keywords Myelodysplastic syndrome $\cdot$ Refractory anemia $\cdot$ Acute lymphoblastic leukemia $\cdot$ Refractory anemia with excess blasts

The myelodysplastic syndrome (MDS) represents a spectrum of stem cell malignancies that manifests dysplastic and ineffective hematopoesis, which is associated with a variable risk of transformation to acute leukemia. Patients have a deteriorating course with $30 \%$ evolving into acute leukemia usually of myeloid phenotype [1]. Evolution into acute lymphoblastic leukemia (ALL) is rare and seen in $<1 \%$ adult cases and extremely rare in pediatric population. There is only one other case report where a child with refractory anemia (RA) transformed into ALL [2]. We report another case where a 5 year old child presenting with refractory anemia with excess blasts (RAEB) evolved into ALL.

V. Gupta $(\bowtie) \cdot$ B. Bhatia

Department of Pediatrics, Institute of Medical Sciences,

Banaras Hindu University, Varanasi 221005, India

e-mail: vineetaguptabhu@gmail.com

\section{Case Report}

A five year old female child presented with one month history of fever, pallor and fatigue. There was history of petechiae over body for last seven days. She had received two units of blood transfusion before admission. On examination, the child had pallor with just palpable spleen. Liver was palpable $1 \mathrm{~cm}$ below costal margin. There was no lymphadenopathy. Her hemoglobin was $5 \mathrm{~g} / \mathrm{dL}$, total leucocyte count (TLC) $14 \times 10^{9} / \mathrm{L}$ and platelet count was $10 \times 10^{9} /$ L. Peripheral smear showed normocytic red blood cells with marked reduction in platelets. No abnormal cells were noted. Bone marrow aspirate was particulate hyper cellular with dyserythropoesis and dysmegakaryopoesis. Blasts were $12 \%$. A diagnosis of refractory anemia with excess blasts (RAEB) was made. The child was given supportive treatment with packed cells, platelet transfusion and broad spectrum antibiotics. She showed improvement and was discharged on request.

She presented 4 months later with fever, pallor and vague pain in limbs. On examination, liver was palpable $5 \mathrm{~cm}$ and spleen was $3 \mathrm{~cm}$ below costal margin. There was sternal tenderness. The hemoglobin was $9 \mathrm{~g} / \mathrm{dL}$ and TLC was $8 \times 10^{9} / \mathrm{L}$. The platelet count was $40 \times 10^{9} \mathrm{~g} / \mathrm{L}$. A repeat bone marrow aspiration showed $90 \%$ blasts which were negative for sudan black and myeloperoxidase. Immunophenotype revealed that these blasts were positive for CD19, 20 and 22 and negative for T cell and myeloid markers. A final diagnosis of MDS-RAEB with transformation to B cell ALL was made. Cerebrospinal fluid was negative for blast cells.

Child was started on modified UK MRC X protocol with vincristine, L-asparaginase, prednisolone and intra-thecal methotrexate. She responded well to the treatment and achieved complete remission in 4 weeks. She received 
Table 1 Profile of patients of MDS transforming to ALL

\begin{tabular}{|c|c|c|c|c|c|c|c|}
\hline S. no. & $\begin{array}{l}\text { Age } \\
\text { (Years) }\end{array}$ & Gender & $\begin{array}{l}\text { MDS } \\
\text { subtype }\end{array}$ & $\begin{array}{l}\text { Time to } \\
\text { progression } \\
\text { (months) }\end{array}$ & Phenotype & Cytogenetics & Outcome \\
\hline 1 & 68 & M & RARS & 31 & B cell & +8 & Expired \\
\hline 2 & 9 & M & RA & 21 & B cell & NA & Lost \\
\hline 3 & 68 & $\mathrm{~F}$ & RAEB & 5 & B cell & $-3,5 q$ & Expired \\
\hline 4 & 54 & M & RA & 30 & B cell & $\mathrm{Ph}, 20 \mathrm{q}-$ & Expired \\
\hline 5 & 50 & M & RA & 4 & B cell & Complex & $\mathrm{CR}$ \\
\hline 6 & 43 & M & NA & NA & B cell & Complex & Expired \\
\hline 7 & 46 & M & RAEB & 2 & B cell & NA & $\mathrm{CR}$ \\
\hline 8 & 70 & M & RA & 22 & B cell & NA & NA \\
\hline 9 & 68 & $\mathrm{~F}$ & RA & 2 & B cell & NA & NA \\
\hline 10 & 65 & M & RA & 18 & B cell & +13 & PR \\
\hline 11 & 28 & $\mathrm{~F}$ & RA & 11 & B cell & Normal & Refractory \\
\hline 12 & $65-72$ & $\begin{array}{l}5 \mathrm{M} \\
1 \mathrm{~F}\end{array}$ & $\begin{array}{l}\text { 1RA } \\
2 \text { RARS } \\
3 \text { RAEB }\end{array}$ & $4-18$ & T cell (all 6) & Variable & $\begin{array}{l}2 \text { Expired } \\
4 \mathrm{CR}\end{array}$ \\
\hline 13 & 75 & M & RAEB & 18 & $\mathrm{~T}$ cell & Normal & NA \\
\hline 14 & 53 & M & CMML & 42 & $\mathrm{~T}$ cell & Normal & PR \\
\hline 15 & 53 & M & RARS & 50 & Null cell & NA & $\mathrm{CR}$ \\
\hline 16 & Elderly & M & & & NA & NA & NA \\
\hline 17 & 58 & M & RA & 20 & NA & NA & Expired \\
\hline 18 & 50 & $\mathrm{~F}$ & RAEB & 3 & NA & Normal & Well (5 years) \\
\hline 19 & 67 & M & RARS & 24 & NA & Aneuploidy & $\mathrm{CR}$ \\
\hline 20 & 20 & M & RAEB & 5 & $\mathrm{~T}$ cell & NA & CR (2 years) \\
\hline Our case & 5 & M & RAEB & 4 & B cell & NA & CR (1.5 years) \\
\hline
\end{tabular}

$C R$ complete remission, $P R$ partial remission, $N A$ not available, $R A$ refractory anemia, $R A R S$ refractory anemia with ring sideroblasts, $R A E B$ refractory anemia with excess blasts, $C M M L$ chronic myelomonocytic leukemia, $M D S$ myelodysplastic syndrome, $A L L$ acute lymphoblastic leukemia

early intensification with daunorubicin, cytosine arabinoside, etoposide and 6-thio guanine. Child is on maintenance therapy and has remained well for last one and a half years.

\section{Discussion}

Childhood MDS is relatively rare in comparison to MDS encountered in adults. It accounts for less than 5\% of all hematopoetic neoplasms in patients less than 14 years of age [3]. A cut off value of $20 \%$ peripheral and/or medullary blasts has been used to separate MDS from acute leukemia $[4,5]$. Unlike majority of cases with adult MDS who may remain asymptomatic for many years, most of the pediatric patients are symptomatic and have a more aggressive course, rapidly transforming to acute myeloid leukemia. However, evolution to acute lymphoblastic leukemia has been reported only occasionally in pediatric patients. 25 cases of MDS transforming to ALL have been reported in literature (Table 1) [6-8] of which only one patient was below 14 years of age. There was male predominance with
20 males and 5 females. The median time to transformation was 5 months (2-50 months). The different types of myelodysplasia were RA (39\%), RAEB (35\%), RARS (22\%) and CMML (4\%). Majority of the patients transformed to B-cell followed by T-cell and null cell. The cytogenetic work up where available and the treatment outcome has been presented in Table 1. There was only one patient in the pediatric age group (9 years) who presented with RA and transformed into B-cell ALL after 21 months. In our patient the initial presentation was RAEB which evolved to B-cell ALL in 4 months. The child responded well to chemotherapy and achieved complete remission. To our knowledge, this is the youngest reported case of MDS transforming into ALL. The case is being presented for its rarity.

\section{References}

1. Tilak V, Sookmane DD, Gupta V, Shukla J (2008) Myelodysplastic syndrome. Indian J Pediatr 75:729-732 
2. Goel R, Kumar R, Bakhshi S (2007) Transformation of Childhood MDS-refractory anemia to acute lymphoblastic leukemia. J Pediatr Hematol Oncol 29:725-727

3. Tuncer MA, Pagliuca A, Hicsomnez G, Yetgin S, Ozsoylu S, Mufti GJ (1992) Primary myelodysplastic syndrome in children: the clinical experience in 33 cases. Br J Haematol 82:347-353

4. Gerning U, Aul C, Niemeyer CM, Haas R, Bennett JM (2008) Epidemiology, classification and prognosis of adults and children with myelodysplastic syndromes. Ann Hematol 87:691-699

5. Hasle H, Niemeyer CM, Chessells JM, Baumann I, Bennet JM, Kerndrup $G$ et al (2003) A pediatric approach to the WHO classification of myelodysplastic and myeloproliferative diseases. Leukemia 17:277-282
6. Zainina S, Cheong SK (2006) Myelodysplastic syndrome transformed into acute lymphoblastic leukemia (FAB: L3). Clin Lab Haematol 28:282-283

7. Sato N, Nakazato T, Kizaki M, Ikeda Y, Okamoto S (2004) Transformation of myelodysplastic leukemia to acute lymphoblastic leukemia: a case report and review of literature. Int J Hematol 79:147-151

8. Naithani R, Kumar R, Saxena R, Mahapatra M (2009) Transformation of myelodysplastic syndrome to T-cell acute lymphoblastic leukemia in a young adult. Pediatr Hematol Oncol 26:100-102 